\title{
Post-Secular Esotericism?
}

\section{Some Reflections on the Transformation of Esotericism}

Tn the last fifteen years the study of Western esotericism has become 1 an academic discipline in its own right. The vast majority of research conducted within the field is focused on older, historical developments, with recent expressions of esotericism receiving far less attention. This has a bearing on the conceptual and methodological tools used in the field as well. The dominant definition of Western esotericism developed by Antoine Faivre might not be entirely suitable when looking at its contemporary expressions. In the late twentieth and early twenty-first centuries Western societies have undergone major processes of transformation, resulting in what many sociologists variously term late modernity, liquid modernity, post-modernity, high modernity (and so forth). Naturally, these transformations affect esoteric spiritualities as well. In this article I will discuss late modern societal transformation and relate this to Western esotericism.

\section{Western Esotericism}

There have been many different scholarly conceptions and definitions of what esotericism actually is. In this context I will only provide a brief discussion of two theoretical models. Further information on other interpretations can be found in, for example, Hanegraaff 1998, 2001 and 2004, and Granholm, forthcoming.

In 1992 Antoine Faivre formulated a characterization of Western esotericism which has become very popular among scholars of esotericism. It can even be regarded as one of the central factors leading to the study of esotericism as a discipline in its own right. Faivre posits Western esotericism as 'an ensemble of spiritual currents in modern and contemporary Western history which share a certain air de famille, as well as the form of thought which is its common denominator' (Faivre 1998: 2). This collection of spiritual currents is furthermore characterized by 
four intrinsic and two extrinsic features. The intrinsic characteristics consist of the ideas of correspondences and living nature, the primacy of mediation and imagination as paths to spiritual insight, and the goal of transmutation. The secondary, non-essential elements consist of specific modes of transmission and a view of the concordance of religious philosophies (Faivre 1994: 10-15). Furthermore, Faivre determines that Western esotericism proper came into existence during the Renaissance, when different religious practices and traditions were combined under a common frame of reference (Hanegraaff 1996: 386-8). The problem with Faivre's model is that it is presented as strictly prescriptive, where all the main characteristics need to be present in order for something to be defined as belonging to esoteric thought. As the definition is based on a historically limited source material, Renaissance esotericism will easily appear to be more truly esoteric than later (or earlier) expressions of esotericism.

In 2005 Kocku von Stuckrad presented an alternative view of esotericism, although he did not present it as a definition per se. Here esotericism is regarded as a structural element in Western culture, consisting of discourses of 'higher knowledge' and 'ways of accessing higher knowledge', including mediation by higher beings and personal experiences of the divine. Stuckrad furthermore suggests that esoteric worldviews are often based on ontological monism (Stuckrad 2005a, 2005b). An important point is that no strict list of necessary attributes is presented, and this discursive approach to esotericism therefore makes it easier to discuss esotericism of various historical periods. The problem with Stuckrad's conception is that it easily becomes all too inclusive. Nonetheless, these two models of esotericism are not in absolute opposition. The idea of ontological monism in von Stuckrad's conception is similar to the characteristics of correspondences and living nature in Faivre's model. Mediation and personal experience/imagination are regarded as important ways of accessing esoteric knowledge in both conceptions.

In my opinion it would be beneficial for the study of esotericism in different epochs to assume a more inclusive model, such as the one presented by von Stuckrad. More strictly delimited models can be used for specific historical periods. 


\section{The Transformation of Esotericism}

While Antoine Faivre's typology of esotericism has been much used, it has also been criticized by a number of scholars (e.g. Hanegraaff 1998: 46-7 and 2004: 508; McCalla 2001; Stuckrad 2005b: 5). The main reason is that Faivre's definition is derived from a historically limited source material, and that the field under study easily appears static and unchanging due to this. The Faivrean conception of esotericism is most applicable to the Renaissance period: esotericism in other periods will diverge from his model. For example, Wouter Hanegraaff proposes that as the Enlightenment may be said to have brought with it big changes for esoteric worldviews, these changes need to be properly reflected upon (Hanegraaff 1996: 406-10 and 2003). Naturally the transformation of esotericism did not start or stop with the Enlightenment. It is problematic to directly apply concepts developed on the basis of Renaissance esotericism on contemporary esotericism. Some re-interpretations are needed. I will briefly discuss some of the central changes in esotericism since the enlightenment, as documented by other scholars, and then focus on the present day situation.

\section{Enlightenment Influences}

The Enlightenment brought with it great changes in many areas of human life. Anthony Giddens identifies Enlightenment ideals, in conjunction with the industrial revolution, as the main driving forces behind the modernization of the West (Giddens 1990: 5, 1991: 55). Reason and scientific rationality were introduced as the ideals of the time, and were set in opposition to the 'superstitious, dogmatic, and barbaric' religious imperative of old. Thus, processes of secularization, where religion gradually came to lose institutional power, gained a strong foothold in Western societies. These processes did not, however, entail the death of religion and spirituality. Rather, new forms of religiosity-and esotericism-emerged, forms that strived to comply with the new rationalistic ideals and that consequently drew heavily on concepts derived from the sciences. In Wouter Hanegraaff's terms, disenchanted forms of esotericism followed. In his article 'How Magic Survived the Disenchantment of the World' Hanegraaff makes use of Lucien Lèvy-Bruhl's notions of participation and instrumental causality, and defines disenchantment as: 
... the social pressure exerted upon human beings to deny the spontaneous tendency of participation, by accepting claims of a culturally established ideology according to which instrumental causality amounts to a worldview capable, in principle, of rationally explaining all aspects of reality (Hanegraaff 2003: 377).

Another general change was the diminishing influence of Christianity, and a consequential increasing interest in non-Christian religious traditions and non-Western cultures. Esotericists had earlier been forced to legitimate their practice as genuinely Christian, in the face of accusations of operating with demonic powers. With the Enlightenment they increasingly started to argue for the compatibility of esoteric and scientific worldviews (Hanegraaff 2003: 369-71). The interest in nonChristian cultures included ancient Egypt, India, native cultures, and pre-Christian Europe. Darwin's theory of evolution was one of the most important scientific fads of the late nineteenth century. This was incorporated in views of spiritual evolution, evident in the Theosophical Society's understanding of reincarnation. A development gaining much influence in the twentieth century was the use of the new discipline of psychology, where esoteric elements were now re-interpreted in psychological framesets, in what Hanegraaff calls 'the psychologization of religion and sacralization of psychology' (Hanegraaff 1996: 482). The Enlightenment, and modernity in itself, also saw the rise of individualism, which resulted in distinct forms of doctrinal and social organization (Hammer 2001: 51-2).

Hanegraaff identifies two major strands of post-Enlightenment esotericism; Romanticism and Occultism (Hanegraaff 1996). In his discussion of the post-Enlightenment change in esotericism, in the West, Wouter Hanegraaff relies strongly on Isaiah Berlin's work on the Enlightenment and counter-Enlightenment (Hanegraaff 1996: 411-15). It is important to note, as Hanegraaff and Berlin do, that the Enlightenment was not essentially anti-religious per se. It included strong sentiments about the possibility and indeed necessity of arriving at absolute knowledge about the world through reason, rationality, and a recourse to essentially unchanging and definitive natural laws. Thus, the form of religiosity mostly attacked by Enlightenment philosophy was traditional, dogmatic Christianity. The Enlightenment tendencies naturally had their counter-forces, discussed by Berlin as the counter-Enlightenment. Where Enlightenment thinkers emphasized universality, objectivity, and rationality, counter-Enlightenment thinkers relied on the particular, on subjectivity, and on the irrational (or supra rational). In Hanegraaff's 
understanding of Berlin the counter-Enlightenment comprises two main developments: the rise of 'historical consciousness' as a result of the rejection of the universal, and sceptical and relativistic attitudes towards universal knowledge.

Romanticism developed in the clash of Enlightenment and counterEnlightenment philosophies and positions. According to Hanegraaff it arose within a stream which combined elements of enlightenment, historicism, and esotericism. Thus, romanticism is deeply indebted to Enlightenment positions, and does not involve a return to earlier, preEnlightenment forms of esotericism (Hanegraaff 1996: 415). For example, while 'the cosmic life-force' was considered to be beyond the rational, and thus irrational, or supra rational, reason was considered the faculty through which it could be accessed (Hanegraaff 1996: 415).

Hanegraaff considers Romantic religiosity to be the product of eighteenth century esotericism and evolutionism. It has largely retained the four major characteristics of Faivre's conceptualization of esotericism, but with a significant difference in the fourth one-the experience of transmutation. In Romanticism transmutation was reinterpreted within an evolutionist frame of reference, where the spiritual progress of both the individual and the world was teleological in nature, with both a beginning and an end (Hanegraaff 1996: 420-1).

Romanticism saw the emergence of Naturphilosophie, which entailed a new approach to nature. According to Antoine Faivre the Romanticist view of nature included seeing it filled with decipherable symbols which pointed to causes and factors outside nature, a readiness to regard nature as an interconnected whole rather than as separated parts, and the view of spirit and nature as combined (Faivre 1994: 82-3). A logical outcome of this philosophy was that knowledge of nature was thought also to be knowledge of oneself.

The idea of a Philosophia Perennis, the search for a unifying inner core of some or all religions, which would then be regarded as truth beyond history, also experienced changes in Romantic esotericism. During the Renaissance the search for an eternal philosophy had mostly been confined to the Mediterranean traditions and teachings. During Romanticism the scope of esoteric interest was broadened to include oriental cultures, which did in fact eventually become its primary focus (Faivre 1994: 86-7; Hanegraaff 2003: 377 and 2007: 44-5).

In addition to oriental traditions, interest in indigenous European pre-Christian traditions began to arise. These traditions were seen as more pure, authentic, and nature friendly than the Christian traditions. In 1891 the Christian apologist W. F. Barry coined the term neopaganism 
as a critique of those showing an interest in pre-Christian pagan traditions (Hutton 1999: 19-20).

The other major post-Enlightenment stream of esotericism Wouter Hanegraaff discusses is occultism. Whilst the application of the label of occultism has been objected to by other scholars, a general consensus about the correctness of Hanegraaff's characterization exists (see Hammer 2001: 5-7; Faivre 2005: 6781). Occultism, also termed 'secularized esotericism' by Hanegraaff, entailed the reinterpretation of esoteric cosmologies in terms of the new scientific worldview. Hanegraaff terms occultism as 'all attempts by esotericists to come to terms with a disenchanted world' (Hanegraaff 1996: 422, 2005: 888). Of the characteristics listed by Faivre the ideas of correspondences and living nature were most drastically transformed. The pre-Enlightenment view of organic and divine forces imbuing the world re-emerged in the form of ideas of invisible, and impersonal, causal laws of nature. The esotericist now manipulated the mechanism by which nature (the world) was constituted. The adoption of pseudo-scientific discourse is one of the more important rhetorical strategies of post-Enlightenment esotericism (Hammer 2001).

Even though Hanegraaff's discussion of the effects of the Enlightenment imperatives of reason on esotericism is sound, his use of the term secularization is more problematic. He details occultism as a secularized form of esotericism and secularization not as the disappearance of religion, but as 'a profound transformation of religion' (Hanegraaff 2003: 358). In Hanegraaff's opinion 'secularized religion' is both religious and secularized, and 'the only thing it is not is "traditional", in the sense of resting on presuppositions which are unaffected by secularization' (Hanegraaff 1996: 409). While agreeing that the Enlightenment caused significant transformations in the European religious field, Christopher Partridge is highly critical of Hanegraaff's understanding of secularization. According to him it leads into 'a thicket of terminological and theological problems' (Partridge 2004: 40). He feels that this profound transformation must be termed something other than secularization, and that the conception of 'secularized magic' is highly problematic.

In the final decades of the twentieth century scholars of religion identified the emergence of novel forms of loosely organized and individualistically focused spiritual ideas and practices. As scholars felt that there were significant similarities in the various manifestations of these ideas and practices, although they often exhibited much variation and diversity, they were gathered under the umbrella term of 'the New Age Movement', at times expressed as 'New Age spirituality', 'New Age re- 
ligion', or simply 'New Age'. The term 'New Age' was chosen due to the fact that early proponents of the identified milieu were expressing the idea that humanity as a whole was on the verge of shifting from the 'Age of Pisces' to the 'Age of Aquarius', and that a 'New Age' was thus dawning. The roots of the 'movement' were traced to the New England transcendentalists and a subsequent American metaphysical tradition (York 1995: 33), the Californian alternative spiritual and mind-expanding drug-taking milieu of the 1940s and 1950s (Heelas 1996a: 49-50; Hammer 1997: 69-79; Aadnanes 1997: 202), as well as the American counter-culture of the 1960s and 1970s (Lewis \& Melton 1992: xi; Ahlin 2001: 16-19). Wouter Hanegraaff discusses the connection between traditional Western esotericism and 'New Age Religion', and even though he states that these are 'worlds apart' (Hanegraaff 2007: 49) he also acknowledges the roots of the latter in the former. 'New Age Religion' is a prime example of what Hanegraaff identifies as secularized esotericism, as it consists of Western esotericism interpreted from 'distinctly modernist and secular frameworks' (Hanegraaff 2007: 49).

While most scholars have wholeheartedly embraced the concept of the 'New Age movement', there are those who acknowledge the problematic nature of this academic construct (see e.g. Sutcliffe 2003: 21-5). Scholars have been unable to present a convincing and compelling definition of the 'movement' in question, often simply presenting very inclusive lists of elements that may or may not be part of a particular 'New Age' phenomenon, discussing their linkages in terms of Wittgensteinian 'family resemblances' (see e.g. Lewis 1992: 7; Hammer 1997: 18-19; Chryssides 1999: 315). George Chryssides attempts to defend the continuing usage of the term by comparing it to other theoretical constructs such as Hinduism. He writes: 'Scholars continue to write about Hinduism, for example, usually in the full knowledge that the term is a western, etic piece of vocabulary...' and goes on to say that the term is useful as it 'has become so embedded in western thinking that it would be difficult to change it' (Chryssides 2007: 13-14). I am unconvinced by this line of argument, and I am not even sure that this is sufficient reason to continue using the term Hinduism. In regard to the term 'New Age', however, certainly it cannot be as deeply imbedded in Western thinking as the term 'Hinduism'. It has been used in scholarly contexts for less than twenty years.

Another problem is that it is becoming increasingly difficult to find 'New Agers' who actually define themselves as 'New Agers', as proponents of the continuing use of the term readily agree (see e.g. Chryssides 2007: 12; Hanegraaff 2007: 29). One of the more influential pioneers in 
the study of the phenomenon has even discussed the 'Death of the New Age' (Melton 2007: 89-91). While it can be argued that there did exist a short-lived, loosely organized spiritual movement focused on the dawning of a New Age for humanity, this movement no longer truly exists. Thus, it would, in my opinion, be prudent to forgo the term 'New Age' as a denomination of the 'post-New Age' spiritual milieu.

There certainly did exist a New Age movement, and this movement was a very significant factor-if not the most important-in the masspopularization of esotericism. Approaching the New Age movement in this fashion has the benefit of escaping the often cumbersome lists of 'family traits'. Naturally, not everything which is labelled under the concept 'New Age' will fit into the concept of 'mass-popularized esotericism' and at the same time some elements not included in the former might be included in the latter. In my opinion, this is not a problem.

\section{Late Modern Societal Change}

Both the Renaissance and the Enlightenment were periods of great change in the West, significantly transforming esoteric philosophies. While not downplaying the impact of these transformations, it can be argued that Western societies are currently undergoing processes of rapid societal change. Sociologists use varying terms to describe the present condition, including the Risk Society (Beck 1992), High or Late Modernity (Giddens 1990, 1991), Liquid Modernity (Bauman 2000), and Post-modernity ${ }^{1}$ (e.g. Bauman 1992, 1997; Crook et al. 1992), and while there are some differences in the accounts, the following can be asserted as a general depiction: Late modernity is characterized by an ambivalent attitude towards 'the institutions and self-evidents of modernity' (Giddens 1991: 27-8). The ideologies of reason and rationality; the benefits of technological and scientific progress, and institutional order-which became hegemonic in Enlightenment developments-have been questioned (Giddens 1990: 10). While modernity brought with it an increased freedom for the individual to affect the course of his/her

1 It should be noted that there is a difference in the content of the term postmodernity in the use of Bauman and in the use of Jean-Francois Lyotard (1984) (and others such as Francis Fukuyama) who popularized the term. While Bauman seems to regard post-modernity largely as a phase of modernity, Lyotard and Fukuyama seem to regard it as all-together different from modernity. 
life, this also introduced new uncertainties. The multiplicity of possibilities and the necessity of making choices that may have far-reaching effects may be experienced as stressful and risk-filled (as every choice could be the wrong one!).

Many scholars regard the changing dialectic of differentiation and de-differentiation as a central theme in the various stages of modernity (see Crook et al. 1992; Heelas 1998). With the modernization of Western societies, previously connected spheres of life were increasingly differentiated and relegated to their own separate domains. Thus, divisions between home and work, private and public, high and mass culture, as well as concepts of race and national identity, became influential social realities. In late modernity the differentiation of social and cultural spheres has intensified to the point of fragmentation, and this has paradoxically led to a form of de-differentiation, where various cultural forms co-exist side by side and flow into each other (Crook et al. 1992: 36-7).

Globalization has been one of the buzzwords in sociology during the last two decades. Scholars disagree on the extent of the connection between modernity and globalization, as well as on the timeframe of the latter (see Giddens 1990: 53; Pieterse 1995: 46-7; Robertson 1995: 30), but generally agree that globalization has accelerated in recent times (Waters 1995: 4; Martikainen 2004: 41). Roland Robertson, one of the central theorists in the field, defines globalization as the compression of the world and the increasing awareness of the world as one interconnected place (Robertson 1992: 8; see also Waters 1995: 3; Friedman 1995: 70). In late modernity, both of these aspects are accentuated due to advances in communication (e.g. the internet and e-mail) and transportation technologies (e.g. faster and more affordable travel and transportation of goods) (Friedman 1995: 70; Waters 1995: 33-6).

Transnationality is another central term in sociological discussion of contemporary social relations. Ulf Hannerz criticizes what he regards as the use of globalization for 'just about any processes or relationships that somehow cross state boundaries' (Hannerz 1996: 6). Instead he suggests the term transnational in reference to social relations and connections which are not necessarily global in context, but nonetheless transcend the boundaries of individual nation states. A benefit of choosing the term transnational over global is that the former highlights the locality of social relations, something which is often not sufficiently treated in theories on globalization (Smith 2001: 2-3). According to Michael Peter Smith, theories of globalization often dichotomize the global and the local in ways that make the two appear essentially distinct (Smith 2001: 
157). Smith uses the concept translocality to denote the connections between various localities in transnational networks (Smith 2001: 169). In essence the different localities in a transnational network will affect and be affected by all other localities.

Secularization, defined by Paul Heelas as 'the processes whereby religion (or spirituality) either disappears from the public realm of the institutional order, or disappears from the lives of individuals, or both' (Heelas 2002: 375), was taken more or less as an indisputable fact by sociologists until the late 1970s. Even though some scholars still hold this view (e.g. Bruce 2002), the apparent resurgence of religion in the West in recent decades has caused most sociologists to drastically change their view on the matter. This renewed religiosity of the West does not, however, mean that processes of secularization never occurred (see Berger 2002: 292). Rather, what we have been experiencing in recent times is 'de-secularization' (Berger 2002) or 're-enchantment' (Partridge 2004, 2005) of a world which, for a relatively brief time, was dominated by secularizing processes.

As discussed earlier, Wouter Hanegraaff's conceptualization of a profound transformation of religion (and esotericism) due to Enlightenment influences is basically sound, even though it should be termed something other than secularization (Partridge 2004: 40). A possible term for this 'profound transformation' could be detraditionalization, as discussed in the anthology of the same name edited by Paul Heelas, Scott Lash and Paul Morris (1996). On a general level, 'tradition' can be defined as 'anything which is transmitted or handed down from the past', and is manifested in the hermeneutic, normative, legitimating and/or identity-forming aspects of a culture (Thompson 1996: 91$3)$. Detraditionalization can then be regarded as the process in which some or all of these factors lose their influence in human life. In regard to religion, Paul Heelas defines detraditionalization as 'the decline of the belief in pre-given or natural orders of things' where individuals 'are themselves called upon to exercise authority in the face of disorder and contingency which is thereby generated' (Heelas 1996b: 2). Heelas names the two main scholarly approaches to detraditionalization 'the radical thesis' and 'the coexistence thesis' (Heelas 1996b: 2-11). In the former, detraditionalization is thought to involve the more or less total replacement of traditional values, beliefs and ways of conduct with new ones. In the latter, detraditionalization is considered to occur alongside tradition-maintenance, rejuvenation and tradition-construction, and does so in different ways (competition, dialogue, interpretation).

Connected to the concepts of secularization, pluralization and detra- 
ditionalization, a central theme in the sociology of religion for the last decade has been the emergence of new forms of alternative spirituality at the expense of traditional institutional religion (see e.g. Heelas 1996a, 2002; Partridge 2004, 2005; Vink 2007). Paul Heelas and Linda Woodhead, chief architects of this school of theorizing, have termed this the 'spiritual revolution' (see Heelas \& Woodhead 2005; Heelas 2002). Heelas in particular dichotomizes traditional religion, characterized by a focus on external authority, with spirituality, in which the ultimate authority is attributed to the individual (Heelas 2002). Even though it can be argued that profound changes are occurring in the contemporary Western religious field, the doctrinal and practical components of these forms of religiosity (or spirituality) are not particularly novel. In many cases what is assumed to be 'new' in these forms of religiosity can already be found in Renaissance esotericism.

While the specific elements of contemporary spirituality may not be new, it appears that esoteric components are becoming increasingly popular in the Western religious milieu (see e.g. Sjödin 1998; Partridge 2004, 2005). Christopher Partridge identifies a shift away from Christian culture and towards 'occulture'-i.e. 'the spiritual/mythic/paranormal background knowledge that informs the plausibility structures of Westerners' (2004: 187). In his two-volume work, The Re-Enchantment of the West, he quite convincingly demonstrates the popularity of esoteric ideas in contemporary Western society, discussing 'occultural' influences in literature and film (Partridge 2004: 119-42, and in its 'dark' variants 2005: 239-46), popular music (2004: 143-84, and in its 'dark' variants 2005: 246-55), ecological concerns (2005: 42-81), internet spirituality (2005: 135-64), UFO beliefs (2005: 165-2006, and in its 'dark' variants 2005: 255-76). At a number of conferences I have myself discussed how esotericism comes to expression in popular music, TV-series and comic books. Esotericism is used as a theme in cultural products because it sells, and it sells because somewhere it strikes a chord with the consumer.

\section{Post-Secular Esotericism?}

In respect of the general processes of globalization, detraditionalization and re-enchantment certain assumptions can be made with regard to esoteric spirituality in the late modern West.

As an effect of the ease of communication provided by the internet, the formation of transnational networks over vast geographical dis- 
tances is made possible. For example, magic orders such as the Temple of Set and Dragon Rouge, neither with a membership of more than 500, have members throughout the Western world, and beyond. Both orders maintain members-only intranets containing extensive amounts of order material in electronic formats and including the possibility of communicating via web forums. Naturally, this holds true for less organized communities as well. Many neo-pagan groups, particularly Wiccan groups, operate solely over the internet (see Arthur 2002; Lövheim 2003). Translocal tendencies are likewise obvious in the transnational networks of contemporary esoteric movements. The fact that the web page of a relatively small organization such as Dragon Rouge is available in ten different languages displays the readiness to cater for different nationalities and language-groups. Dragon Rouge also represents a good example of different localities adding to the whole transnational network. Lodges and ritual groups located in Poland, Germany, Italy and Finland have all disseminated distinctly local themes, such as treatment of Old Slavic deities and the Finnish national epic Kalevala, in order-wide forums. Some of these themes are then appropriated by members in different localities, where they are transformed to suit their new context (see Granholm 2007).

With increasingly accentuated globalization and transnational networking, the 'Western' aspect of Western esotericism becomes somewhat problematic. As Wouter Hanegraaff has shown, influences from eastern religious traditions, mainly Hindu and Buddhist elements, have become influential in post-Enlightenment esoteric spiritualities. However, he also notes that these influences 'have only been adopted to the extent that they could be assimilated into already existing, western frameworks' (Hanegraaff 2007: 45). However, I would question the definiteness of this seemingly one-way appropriation. In an interesting conference paper Gordan Djurdjevic (2007) has discussed the syncretistic intermingling of eastern yogic philosophy and practices and Western esotericism. At the suggestion of the British magician Aleister Crowley, Lawrence Amos Miles travelled to India in search of occult wisdom. He was initiated into the tantric Ādi Nāth Sampradāya, as well as a number of other yogic traditions, and assumed the name Shri Gurudev Mahendranath Dadaji. Due to increasing contact with Western disciples, he decided to introduce his teachings to the West, and in doing so infused them with concepts from Western esoteric traditions. In this case, and I would assume in many others in contemporary times as well, it becomes increasingly difficult to describe this simply as a case of Indian religiosity clad in the robes of Western esoteric discourse, or vice versa. 
With the possibilities afforded by advances in communication technology and the ease of travel, the mixing of Western and Eastern concepts and ideas will probably increase.

Detraditionalization is apparent in many forms of esoteric spirituality since at least the late nineteenth century. For example, the appropriation of Indian religious concepts by the Theosophical Society (founded in 1888) and the inclusion of Egyptian mythology in the Hermetic Order of the Golden Dawn (also founded in 1888) were essentially separated from their original, traditional contexts. In the process of reembedding these elements into new contexts they were also significantly transformed. In the late twentieth century the eclecticism and pluralistic ethos of occultism has been taken to new levels. Whereas the Theosophical Society was selective in its eclecticism, mainly borrowing from a limited number of Indian religious traditions, late twentieth century esotericism commonly broadens its scope of influence to include every imaginable source. In a magic order such as Dragon Rouge, Old Norse mythology is effortlessly combined with Tantra, Kabbalah, East Asian religious notions, Muslim mysticism, UFO beliefs, and beyond (see Granholm 2005). In addition, academic studies in the fields of anthropology, sociology, history, religious studies, physics, and so forth, are becoming increasingly notable sources of inspiration. This is also apparent in mass-popularized esotericism, or 'the New Age movement', where elements from nearly all religious traditions, past and present, are explored for spiritual inspiration. This contemporary form of esotericism also frequently displays an ambivalent attitude to modern science and the domination of reason and rationality.

From a certain perspective, many forms of contemporary esotericism could be termed 'post-secular'. I have chosen this term, as it places the focus on late modern attempts to 're-enchant' the human existential world, while at the same time engaging in a polemical dialogue with scientific rationality. I again call attention to Wouter Hanegraaff's definition of disenchantment:

... the social pressure exerted upon human beings to deny the spontaneous tendency of participation, by accepting claims of a culturally established ideology according to which instrumental causality amounts to a worldview capable in principle of rationally explaining all aspects of reality (Hanegraaff 2003: 377).

Put simply, participation can be understood as a tendency towards emotive, analogical, non-reasoning thought and action, whereas instrumen- 
tal causality can be understood as a tendency to seek the reasons for events in the world in terms of material causation. ${ }^{2}$ Re-enchantment in post-secular esotericism can be defined as an active effort to acknowledge, embrace and seek affective and analogical thinking and action, while at the same time underscoring the insufficiency of rationality. A key point is the awareness of the ideology of instrumental causality. Post-secular esotericism is not traditionalist in character, or seeking to re-embody pre-Enlightenment esotericism, and it does make use of the faculties of rationality, scientific findings, and the offerings of contemporary society. The central idea is that when it comes to magic and esoteric practice, rationality is simply not the right tool for the job, and when scientific or pseudo-scientific discourse is used, care is taken not to overstress the importance of it. Post-secular esotericism could be termed 'anti-modernist', in the fashion of certain post-modern philosophers. In certain ways this post-secular esotericism resembles the 'romantic stream of esotericism' as defined by Hanegraaff (1996: 409).

In more detail, post-secular esotericism displays traits of both preand earlier post-Enlightenment esotericism. Both scientific and esoteric worldviews and explanatory models are combined. Nature is viewed as animated by active personal forces and correspondences are experienced through non-causal agencies, while at other times the rhetoric of impersonal causal forces is used. These are regarded as different, but not necessarily incompatible, models of explanation, and are both employed in order to achieve what is considered to be a total picture of existence. A collection of seemingly incompatible notions are glued together to form a functionalistic bricolage. (See Granholm, forthcoming.)

In addition, the evolutionary discourses of earlier post-Enlightenment esotericism are abandoned in post-modern disavowals of 'grand narratives'. Instead progress is increasingly being sought and advocated on a purely individual level.

The popularization of esoteric themes, apparent in the 1970s and 1980s (The New Age Movement), has been capitalized on in a grand scale. Esoteric elements have an increasing presence in all forms of popular culture. It is here in particular that new concepts and methodological tools need to be developed.

2 In Hanegraaff's text: participation is 'an affective rather than rational stratum in human thought and action ... analogical rather than logical, and is not reduced to primary reasoning' (Hanegraaff 2003: 375). Instrumental causality, a spontaneous 'tendency to suspect things that happen in the world to be the result of material causation, and to explain events in this fashion' (Levy-Bruhl, quoted in Hanegraaff 2003: 376). 


\section{References}

Aadnanes, Per M.

1997 Det nye tusenårsriket. New Age som livssyn. Oslo: Scandinavian University Press.

Ahlin, Lars

2001 New Age - Konsumtionsvara eller värden att kämpa för? Lund: Lunds universitet.

Arthur, Shawn

2002 Technophilia and Nature Religion: the Growth of a Paradox. Religion 32: 303-14.

\section{Bauman, Zygmunt}

1992 Intimations of Postmodernity. London: Routledge.

1997 Postmodernity and its Discontents. Cambridge: Polity Press.

2000 Liquid Modernity. Cambridge: Polity Press.

Beck, Ulrich

1992 Risk Society. Towards a New Modernity. London: Sage.

Berger, Peter L.

2002 Secularization and De-Secularization. In: Paul Fletcher et al. (eds), Religion in the Modern World. Traditions and Transformations; pp. 291-8. London: Routledge.

\section{Bruce, Steve}

2002 God is Dead: Secularization in the West. Oxford: Blackwell.

Chryssides, George D.

1999 Exploring New Religions. London: Cassell.

2007 Defining the New Age. In: Daren Kemp \& James R. Lewis (eds), Handbook of New Age; pp. 5-24. Leiden: Brill.

Crook, Stephen, Jan Pakulski \& Malcolm Waters

1992 Postmodernization. Change in Advanced Society. London: Sage.

Djurdjevic, Gordan

2007 When Yoga Becomes Magick. Mahendranath, his Disciples, and the Western Esoteric Tradition. Paper presented at the Religion on the Borders conference. Stockholm, Sweden, 20 April 2007.

\section{Faivre, Antoine}

1994 Access to Western Esotericism. Albany: State University of New York Press.

1998 Questions of Terminology Proper to the Study of Esoteric Currents in Modern and Contemporary Europe. In: Antoine Faivre \& Wouter J. Hanegraaff (eds), Western Esotericism and the Science of Religion; pp. 1-10. Leuven: Peeters.

2005 Occultism. In: Lindsay Jones (ed.), Encyclopedia of Religion; pp. 6780-3. 2nd ed. Detroit: MacMillan.

\section{Friedman, Jonathan}

1995 Global System, Globalization and the Parameters of Modernity. In: Mike 
Featherstone, Scott Lash \& Roland Robertson (eds), Global Modernities; pp. 69-90. London: Sage.

\section{Giddens, Anthony}

1990 The Consequences of Modernity. Cambridge: Polity Press.

1991 Modernity and Self-Identity. Self and Society in the Late Modern Age. Cambridge: Polity Press.

\section{Granholm, Kennet}

2005 Embracing the Dark. The Magic Order of Dragon Rouge - Its Practice in Dark Magic and Meaning Making. Åbo: Åbo Akademi University Press.

2007 "The Prince of Darkness on the Move". Transnationality and Translocality in Left-Hand Path Magic. Torino: CESNUR. URL: http: / www.cesnur. org/2007/ bord_granholm.htm (accessed 2 March 2007).

Forthcoming The Sociology of Esotericism. In: Peter B. Clarke (ed.), The Oxford Handbook of the Sociology of Religion. Oxford: Oxford University Press.

\section{Hammer, Olav}

1997 På spaning efter helheten. New Age - en ny folktro? Stockholm: Wahlström \& Widstrand.

2001 Claiming Knowledge. Strategies of Epistemology from Theosophy to the New Age. Leiden: Brill.

\section{Hanegraaff, Wouter J.}

1996 New Age Religion and Western Culture. Esotericism in the Mirror of Secular Thought. Leiden: Brill.

1998 On the Construction of "Esoteric Traditions". In: Antoine Faivre \& Wouter J. Hanegraaff (eds), Western Esotericism and the Science of Religion; pp. 11-61. Leuven: Peeters.

2001 Beyond the Yates Paradigm: The Study of Western Esotericism between Counterculture and New Complexity. Aries 1 (1): 5-37.

2003 How Magic Survived the Disenchantment of the World. Religion 33: 35780.

2004 The Study of Western Esotericism. New Approaches to Christian and Esoteric Culture. In: Peter Antes, Armin W. Geertz \& Randi R. Warne (eds), New Approaches to the Study of Religion. Volume 1: Regional, Critical and Historical Approaches; pp. 489-519. New York: Walter de Gruyter.

2007 The New Age Movement and Western Esotericism. In: Daren Kemp \& James R. Lewis (eds), Handbook of New Age; pp. 25-50. Leiden: Brill.

\section{Hannerz, Ulf}

1996 Transnational Connections. Culture, People, Places. London: Routledge.

\section{Heelas, Paul}

1996a The New Age Movement. The Celebration of the Self and the Sacralization of Modernity. Oxford: Blackwell.

1996b Introduction: Detraditionalization and its Rivals. In: Paul Heelas, Scott Lash \& Paul Morris (eds), Detraditionalization. Critical Reflections on Authority and Identity; pp. 1-20. Oxford: Blackwell.

1998 Introduction: On Differentiation and Dedifferentation. In: Paul Heelas, 
with the help of David Martin and Paul Morris (ed.), Religion, Modernity and Postmodernity; pp. 1-18. Oxford: Blackwell.

2002 TheSpiritual Revolution: From 'Religion' to 'Spirituality'. In:Paul Fletcher et al. (eds), Religion in the Modern World. Traditions and Transformations; pp. 357-77. London: Routledge.

Heelas, Paul, Scott Lash \& Paul Morris (eds)

1996 Detraditionalization. Critical Reflections on Authority and Identity. Oxford: Blackwell.

Heelas, Paul \& Linda Woodhead (eds)

2005 The Spiritual Revolution: Why Religion is Giving Way to Spirituality. Oxford: Blackwell.

Hutton, Ronald

1999 Modern Pagan Witchcraft. In: Bengt Ankarloo \& Stuart Clark (eds), The Athlone History of Witchcraft and Magic in Europe. Volume 6: The Twentieth Century; pp. 1-79. London: The Athlone Press.

Lewis, James R.

1992 Approaches to the Study of the New Age Movement. In: James R. Lewis \& J. Gordon Melton (eds), Perspectives on the New Age; pp. 1-12. Albany: State University of New York Press.

Lewis, James R. \& J. Gordon Melton

1992 Introduction. In: James R. Lewis \& J. Gordon Melton (eds), Perspectives on the New Age; pp. ix-xii. Albany: State University of New York Press.

\section{Lövheim, Mia}

2003 Religiös identitet på Internet. In: Göran Larson (ed.), Talande tro. Ungdomar, religion och identitet; pp. 119-41. Lund: Studentlitteratur.

Lyotard, Jean-Francois

1984 The Postmodern Condition. A Report on Knowledge. Minneapolis: University of Minneapolis Press.

\section{Martikainen, Tuomas}

2004 Immigrant Religions and Local Society. Historical and Contemporary Perspectives in the City of Turku. Åbo: Åbo Akademi University Press.

McCalla, Arthur

2001 Antoine Faivre and the Study of Esotericism. Religion 31: 435-50.

Melton, J. Gordon

2007 Beyond Millennialism: The New Age Transformed. In: Daren Kemp \& James R. Lewis (eds), Handbook of New Age; pp. 77-97. Leiden: Brill.

Partridge, Christopher

2004 The Re-Enchantment of the West. Volume I: Alternative Spiritualities, Sacralization, Popular Culture, and Occulture. London: T \& T Clark International.

2005 The Re-Enchantment of the West. Volume II: Alternative Spiritualities, Sacralization, Popular Culture, and Occulture. London: T \& T Clark International.

Pieterse, Jan Nederveen

1995 Globalization as Hybridization. In: Mike Featherstone, Scott Lash \& Roland Robertson (eds), Global Modernities; pp. 45-68. London: Sage. 


\section{Robertson, Roland}

1992 Globalization. Social Theory and Global Culture. London: Sage.

1995 Glocalization: Time-Space and Homogeneity-Heterogeneity. In: Mike Featherstone, Scott Lash \& Roland Robertson (eds), Global Modernities; pp. 25-44. London: Sage.

\section{Sjödin, Ulf}

1998 Tror vi på det dolda? Svenskens syn på det paranormala. In: Owe Wikström (ed.), Att se det dolda. Om New Age och ockultism inför millennieskiftet; pp. 51-74. Stockholm: Natur \& kultur.

\section{Smith, Michael Peter}

2001 Transnational Urbanism. Locating Globalization. Oxford: Blackwell.

\section{Stuckrad, Kocku von}

2005a Western Esotericism. A Brief History of Secret Knowledge. London: Equinox.

2005b Western Esotericism: Towards and Integrative Model of Interpretation. Religion 35: 78-97.

\section{Sutcliffe, Steven J.}

2003 Children of the New Age. A History of Spiritual Practices. London: Routledge.

\section{Thompson, John B.}

1996 Tradition and Self in a Mediated World. In: Paul Heelas, Scott Lash \& Paul Morris (eds), Detraditionalization. Critical Reflections on Authority and Identity; pp. 89-108. Oxford: Blackwell.

\section{Vink, Nico T. M.}

2007 Understanding Spirituality Sociologically: Religious Experience Among Dutch Catholics Today. Paper presented at the 2007 SISR/ISSR conference, Leipzig, Germany. 26 July 2007. (The full text can be accessed at http: / / www.nicotmvink.nl; 2 March 2007.)

\section{Waters, Malcolm}

1995 Globalization. London: Routledge.

\section{York, Michael}

1995 The Emerging Network. A Sociology of the New Age and Neopagan Movements. Oxford: Rowman \& Littlefield. 